\title{
Synthesis, Characterization and Crystal Structure of a New Schiff Base Ligand from a Bis(Thiazoline) Template and Hydrolytic Cleavage of the Imine Bond Induced by a Co(II) Cation
}

\author{
Jafar Attar Gharamaleki ${ }^{*}$, Fahimeh Akbari1 ${ }^{1}$, Akram Karbalaei ${ }^{1}$, Kamran B. Ghiassi², \\ Marilyn M. Olmstead2 \\ ${ }^{1}$ Faculty of Chemistry, Kharazmi University, Tehran, Iran \\ ${ }^{2}$ Department of Chemistry, University of California, Davis, CA, USA \\ Email: *attar_jafar@yahoo.com
}

Received 23 December 2015; accepted 26 January 2016; published 29 January 2016

Copyright (C) 2016 by authors and Scientific Research Publishing Inc.

This work is licensed under the Creative Commons Attribution International License (CC BY).

http://creativecommons.org/licenses/by/4.0/

(c) () Open Access

\section{Abstract}

The reaction of bis-[2-amino-4-pheny1-5-thiazolyl] disulfide with 5-nitro-salicylaldehyde in absolute ethanol resulted in the formation of a new Schiff base ligand $\mathrm{H}_{2} \mathrm{~L}$ (1). Characterization of the ligand was performed by FT-IR, ${ }^{1}$ H NMR, ${ }^{13} \mathrm{C}$ NMR, UV-Vis, elemental analysis and single crystal X-ray diffraction. The ligand, (1), possesses a disulfide -S-S- bridge of 2.1121 (3) Å length, and the molecule adopts a cis-conformation around this bond. In the crystal structure of (1), an intramolecular $\mathrm{O}-\mathrm{H} \cdots \mathrm{N}$ hydrogen bond with $\mathrm{D}$... A distance of 2.69 (3) Å was present. The reaction of (1) with $\mathrm{Co}\left(\mathrm{NO}_{3}\right)_{2} \cdot 6 \mathrm{H}_{2} \mathrm{O}$ and $\mathrm{CuCl}_{2} \cdot 2 \mathrm{H}_{2} \mathrm{O}$ in methanol afforded the corresponding metal complexes. The obtained solids were further investigated by elemental analysis and UV-Vis titration that confirmed the formation of [CoL] and [ClCuHL] complexes. However, recrystallizaion of the Co(II) complex in dimethylsulfoxide caused the complete hydrolysis of the imine bond and afforded a Co(II) complex in which two 5-nitro-salicylaldehyde and two DMSO molecules were coordinated to the central metal in an octahedral fashion. This structure (2) was also confirmed by single crystal $\mathrm{X}$-ray analysis.

\section{Keywords}

Schiff Base, Thiazoline Ligand, Disulfide Bond, Co(II) and Cu(II) Complexes, Hydrolytic Cleavage,

*Corresponding author.

How to cite this paper: Gharamaleki, J.A., et al. (2016) Synthesis, Characterization and Crystal Structure of a New Schiff Base Ligand from a Bis(Thiazoline) Template and Hydrolytic Cleavage of the Imine Bond Induced by a Co(II) Cation. Open Journal of Inorganic Chemistry, 6, 76-88. http://dx.doi.org/10.4236/ojic.2016.61005 


\section{Solution Study}

\section{Introduction}

Schiff bases are compounds with the structure consisting of a $\mathrm{C}=\mathrm{N}$ bond, generally formed by condensation of an amine and active carbonyl group, initially developed by Hugo Schiff [1] [2]. Schiff base ligands are easily synthesized and form complexes with almost all metal ions in various oxidation states [3] [4]. These metal complexes can be used in catalytic reactions and as models for biological systems. This may be related to their biological activity, including antibacterial, antifungal, anticancer, antioxidant, anti-inflammatory, antimalarial, antiviral activity as well as applications in a variety of chemical areas such as oxidation, reduction and hydrolysis catalysis [5]-[18]. However, hydrolytic cleavage of Schiff base ligands readily occurs due to the reversible nature of the synthetic procedure. It has been reported that the $\mathrm{C}=\mathrm{N}$ cleavage occurs on a number of metal sites ranging from simple salts to mixed ligand complexes [19]-[22]. However, the solvent system, co-ligands and reaction conditions are also important factors [23]-[25]. The hydrolysis of Schiff bases in the presence of a metal ion is observed by Ghosh and coworkers [26]. They argue that the hydrolysis is dependent on several factors, and was observed such as the $\mathrm{pH}$ of the reaction medium, the size of the chelate rings formed by the diamine fragment of the Schiff base, the coordinating ability of the counter anions, the nature of the metal ions, and the effect of carbonyl compounds [27]-[34]. The amine or aldehyde fragment regenerated by the cleavage of the $\mathrm{C}=\mathrm{N}$ functional group of the Schiff base, can coordinate to the central atom.

Recently, we noticed that a disulfide compound is obtained as a byproduct during the preparation of bis-[2amino-4-pheny1-5-thiazolyl] sulfide by following the procedure reported by Dodson and King [35]. These two products may be separated by means of column chromatography. In this regard, the 5-nitro-salicylaldehyde is prepared and then is used in condensation reaction with synthesized bis-[2-amino-4-phenyle-5-thiazolyl] disulfide. Characterization of the prepared ligand are performed by FT-IR, ${ }^{1} \mathrm{H}$ NMR, ${ }^{13} \mathrm{C}$ NMR, elemental analysis and single crystal X-ray analysis. The reaction of the Schiff base ligand with $\mathrm{Co}$ (II) and Cu (II) salts in methanol affords the $[\mathbf{C o L}]$ and $[\mathrm{ClCuHL}]$ complexes. The obtained solids are further investigated by elemental analysis and UV-Vis titration that confirm the formation of desired complexes. Recrystallization of the Co(II) complex in DMSO results in the cleavage of $\mathrm{C}=\mathrm{N}$ bond to yield (2). The outline of the synthetic procedure is given in Scheme 1.

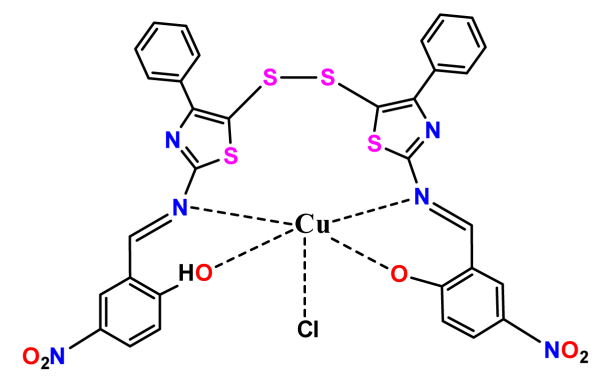

$[\mathrm{ClCuHL}]$

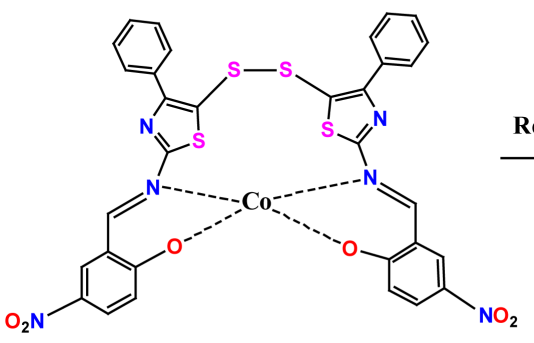

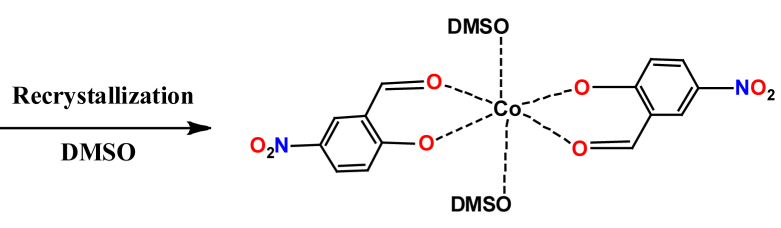

(2)

$[\mathrm{CoL}]$ 


\section{Experimental}

\subsection{Materials and Physical Techniques}

All chemicals were purchased from Merck and used without further purification. FT-IR spectra were recorded in the frequency range of $4000-400 \mathrm{~cm}^{-1}$ with use of a Perkin-Elmer RXI spectrometer using KBr disks at room temperature. Elemental analysis was carried out using a Perkin-Elmer 2400 (II) CHN analyzer. ${ }^{1} \mathrm{H}$ NMR and ${ }^{13} \mathrm{C}$ NMR spectra were recorded with a Bruker Avance 300 spectrometer using DMSO-d ${ }^{6}$ as solvent. UV-Vis spectra were recorded with a Perkin-Elmer Lambda 25 spectrophotometer, using two matched 10-mm quartz cells.

\subsection{Crystal Structure Determination and Refinement}

Crystallographic data for (1) were collected with use of a Bruker Apex DUO diffractometer, $\mathrm{Cu} \mathrm{K}_{\alpha}$ radiation and a Cryosystems low temperature apparatus. The crystal was twinned, and the data reduction was carried out using two components. The twin law was $-10000-100-101$.

Data reduction and cell refinement were carried with SAINT [36]. An absorption correction was applied with use of the program TWINABS [36]. The programs used to solve and refine the structure were SHELXS [37] and SHELXL-2014/7 [38], respectively. The hydrogen atom H4 on the OH group was not located in a difference Fourier map. Its position was estimated based on geometric considerations and its similarity to the position of H1. During refinement, restraints were applied such that $\mathrm{O}-\mathrm{H}$ was $0.84 \AA$. and the $\mathrm{C}-\mathrm{O}-\mathrm{H}-\mathrm{N}$ grouping was flat. The remaining, C-H hydrogen atoms were included as riding on their parent carbon atoms. All hydrogen $\mathrm{U}_{\text {iso }}$ values were set to $20 \%$ more than the $\mathrm{U}_{\text {eq }}$ of their parent atoms.

Data for compound (2) were collected at the Advanced Light Source, Lawrence Berkeley National Lab, California using an Oxford Cryostream low temperature device. The radiation employed was $0.77490 \AA$ and the diffraction apparatus was a Bruker D8 with a PHOTON 100 CMOS detector. This structure was also twinned, with a twin law $-1 \quad 0 \quad-0.2920-100001$. Software programs utilized were the same as for (1). Crystal data and refinement details are reported in Table 1.

\section{Syntheses}

\subsection{Synthesis of 2-Amino-4-phenylthiazole}

The required starting material, 2-amino-4-phenylthiazole, was prepared from acetophenone, iodine, and thiourea through the procedure developed by Dodson [35] and Woodbridge [39]. In a general procedure, to a mixture consisting of 0.2 mole of acetophenone and 0.4 mole of thiourea, 0.2 mole of iodine was slowly added in small portions. After this stage, the reaction mixture was heated overnight on a steam-bath. It was then diluted with cold distilled water and made alkaline with sodium hydroxide. The precipitated 2-amino-4-phenylthiazole was separated and crystallized from an ethanol $/ \mathrm{H}_{2} \mathrm{O}$ mixture. Properties: Yield: $75 \%$, M.p. $=144^{\circ} \mathrm{C}-146^{\circ} \mathrm{C}$, IR (KBr): $\bar{v}\left(\mathrm{~cm}^{-1}\right)$ : 3434(s), 3249(m), 3150(m), 3115(m), 1598(s), 1532(s), 1518(s), 1483(m), 1441(m), 1340(s), 1330(s), 1306(m), 1201(m), 1039(s), 1022(s), 912(s), 845(s), 772(s), 714(s), 667(m), 567(w), 472(m). ${ }^{1} \mathrm{H} \mathrm{NMR}$ $\left(300 \mathrm{MHz}\right.$, DMSO-d $\left.{ }_{6}\right) \delta 7.77-7.80$ (d, 2H, J = 7.3 Hz, ArH), $7.32-7.37$ (t, 2H, J = 7.3 Hz, ArH), 7.21 - 7.25 (t, $1 \mathrm{H}, \mathrm{J}=7.3 \mathrm{~Hz}, \mathrm{ArH}), 7.08\left(\mathrm{~s}, 2 \mathrm{H}, \mathrm{NH}_{2}\right), 6.98(\mathrm{~s}, 1 \mathrm{H}, \mathrm{ArH})$. Elemental Anal. calc. for $\mathrm{C}_{9} \mathrm{H}_{8} \mathrm{~N}_{2} \mathrm{~S}: \mathrm{C}, 61.34 ; \mathrm{H}$, 4.58; N, 15.90. Found: C, 61.02; H, 4.47; N, 15.60\%.

\subsection{Synthesis of Bis-[2-amino-4-pheny1-5-thiazolyl] Disulfide}

2-Amino-4-phenylthiazole ( $3.6 \mathrm{~g}$ ) and $1.52 \mathrm{~g}$ of thiourea were dissolved in $50 \mathrm{~mL}$ mixture of warm ethanol and distilled water. A portion of $7.6 \mathrm{~g}$ of iodine was then added to this solution with stirring. After the addition was completed, the resultant red-brown mixture was refluxed for three hours and then poured into cooled distilled water. The mixture was extracted with dichloromethane $(3 \times 50 \mathrm{~mL})$. The filtrate was concentrated and the crude product purified by column chromatography (silica gel, $\mathrm{CH}_{2} \mathrm{Cl}_{2} / \mathrm{n}$-hexane: $2 / 3 \mathrm{~V} / \mathrm{V}$ ). The fraction containing the desired bis-[2-amino-4-phenyl-5-thiazolyl] disulfide was then made alkaline with sodium hydroxide solution. A yellow precipitate was formed which was further recrystallized from water/acetic acid to give a yellow solid. Properties: Yield: $25 \%$, M.p $=180^{\circ} \mathrm{C}-182^{\circ} \mathrm{C}$. FT-IR (KBr): $\bar{v}\left(\mathrm{~cm}^{-1}\right): 3420(\mathrm{~s}), 3282(\mathrm{~s}), 3192(\mathrm{~s}), 2360(\mathrm{br})$, 1682(s), 1628(s), 1514(s), 1470(s), 1438(m), 1355(m), 1334(m), 1277(s), 1179(w), 890(m), 771(s), 696(s). ${ }^{1} \mathrm{H}$ NMR (300 MHz, DMSO-d $)_{6} \delta 7.76-7.79(\mathrm{~d}, 4 \mathrm{H}, \mathrm{J}=7.3 \mathrm{~Hz}, \mathrm{ArH}), 7.69-7.74(\mathrm{t}, 4 \mathrm{H}, \mathrm{J}=7.3 \mathrm{~Hz}, \mathrm{ArH}), 7.30$ - 
Table 1. Crystal data and refinement analysis for compounds (1) and (2).

\begin{tabular}{|c|c|c|}
\hline Compound & (1) & (2) \\
\hline Formula & $\mathrm{C}_{32} \mathrm{H}_{20} \mathrm{~N}_{6} \mathrm{O}_{6} \mathrm{~S}_{4}$ & $\mathrm{C}_{18} \mathrm{H}_{20} \mathrm{CoN}_{2} \mathrm{O}_{10} \mathrm{~S}_{2}$ \\
\hline Formula weight $\left(\mathrm{g} \mathrm{mol}^{-1}\right)$ & 712.78 & 547.41 \\
\hline Crystal system & Triclinic & Monoclinic \\
\hline Space group & $P-1$ & $P 2_{1} / c$ \\
\hline$a(\AA)$ & $7.2278(8)$ & $11.5457(6)$ \\
\hline$b(\AA)$ & $12.7387(19)$ & $12.2321(6)$ \\
\hline$c(\AA)$ & $17.536(2)$ & $7.6490(4)$ \\
\hline$\alpha\left(^{\circ}\right)$ & $88.916(9)$ & - \\
\hline$\beta\left(^{\circ}\right)$ & $78.336(9)$ & $95.464(3)$ \\
\hline$\gamma\left(\left(^{\circ}\right)\right.$ & $77.712(10)$ & - \\
\hline Volume $\left(\AA^{3}\right)$ & $1544.5(3)$ & $1075.35(10)$ \\
\hline $\mathrm{D}\left(\mathrm{g} \mathrm{cm}^{-3}\right)$ & 1.533 & 1.691 \\
\hline$F(000)$ & 732 & 562 \\
\hline Temperature (K) & $90(2)$ & $100(2)$ \\
\hline Crystal size (mm) & $0.2 \times 0.03 \times 0.02$ & $0.04 \times 0.03 \times 0.01$ \\
\hline$\theta$ range for data collection $\left(^{\circ}\right)$ & 2.5 to 67.1 & 2.7 to 34.7 \\
\hline Index ranges & $\begin{aligned}-7 & \leq h \leq 7, \\
-13 & \leq k \leq 13 \\
0 & \leq l \leq 19\end{aligned}$ & $\begin{aligned}-16 & \leq h \leq 16, \\
-17 & \leq k \leq 17, \\
-8 & \leq l \leq 11\end{aligned}$ \\
\hline$Z$ & 2 & 2 \\
\hline Wavelength $(\AA)$ & 1.54178 & 0.7749 \\
\hline Absorption coefficient $\left(\mathrm{mm}^{-1}\right)$ & 1.533 & 1.32 \\
\hline Data collected & 3882 & 9941 \\
\hline Unique data & 2940 & 3194 \\
\hline parameters/restraints & $440 / 3$ & $153 / 0$ \\
\hline Final $R$ indices $[\mathrm{I}>2 \sigma(\mathrm{I})]$ & $R_{1}=0.071, w R_{2}=0.165$ & $R_{1}=0.048, w R_{2}=0.122$ \\
\hline$R$ indices (all data) & $R_{1}=0.092, w R_{2}=0.177$ & $R_{1}=0.057, w R_{2}=0.125$ \\
\hline Goodness-of-fit on $F^{2}(S)$ & 1.02 & 1.19 \\
\hline Largest diff. peak and hole, (e. $\AA^{-3}$ ) & 0.66 and -0.63 & 0.74 and -0.46 \\
\hline
\end{tabular}

7.35 (t, 2H, J = $7.3 \mathrm{~Hz}, \mathrm{ArH}), 7.60$ (s, 4H, NH$\left.{ }_{2}\right) .{ }^{13} \mathrm{C}$ NMR, (d $\left.\mathrm{d}^{6} \mathrm{DMSO}\right) \delta$, ppm: 109.9, 128.4, 128.8, 129.8, 134.7, 159.4 and 171.9. Elemental Anal. calc. for $\mathrm{C}_{18} \mathrm{H}_{14} \mathrm{~N}_{4} \mathrm{~S}_{4}$ : C, 52.15; H, 3.40; N, 13.51. Found: C, 51.95; H, 3.27; N, 13.37\%.

\subsection{Synthesis of 5-Nitro-salicylaldehyde}

This substrate was prepared according to the method described in [40]. Properties: Yield: 63\%, Yellow solid; M.p. $=120^{\circ} \mathrm{C}-122^{\circ} \mathrm{C}$. FT-IR (KBr): $\bar{v}\left(\mathrm{~cm}^{-1}\right): 3069(\mathrm{~m}), 2886(\mathrm{w}), 1665(\mathrm{~s}), 1627(\mathrm{~m}), 1579(\mathrm{~m}), 1509(\mathrm{~m}), 1473(\mathrm{~s})$, 1343(s), 1287(s), 1181(w), 929(m), 914(m), 771(m), 718(s), 633(s), 462(w). ${ }^{1} \mathrm{H}$ NMR (300 MHz, DMSO-d $d_{6}$ ) $\delta 10.2$ (s, 1H, aldehyde-H), 8.34 (s, $1 \mathrm{H}, \mathrm{ArH}), 8.25$ - 8.28 (d, $1 \mathrm{H}, \mathrm{J}=8.1 \mathrm{~Hz}, \mathrm{ArH}), 7.12$ - 7.16 (d, 1H, J = 8.1 Hz, ArH), 8.01 (s, $1 \mathrm{H}, \mathrm{OH}$ ). Elemental Anal. calc. for $\mathrm{C}_{7} \mathrm{H}_{5} \mathrm{NO}_{4}$ : C, 50.31; H, 3.02; N, 8.38. Found: C, 50.15; H, 
$3.17 ; \mathrm{N}, 8.28 \%$.

\subsection{Synthesis of 1,1'-((1E,1'E)-((5,5'-Disulfanediylbis(4-phenylthiazole-5,2-Diyl)) Bis(azanylylidene))bis(methanylylidene))bis(5-nitrobenzene-2-ol), Schiff-Base (1)}

To a solution of 5-nitro-salicylaldehyde $(0.34 \mathrm{~g}, 2 \mathrm{mmol})$ in absolute ethanol $(20 \mathrm{~mL})$ was added bis-[2-amino4-phenyl-5-thiazolyl] disulfide $(0.41 \mathrm{~g}, 1 \mathrm{mmol})$ in ethanol. After the addition, the solution was refluxed overnight. The obtained orange precipitation was filtered, washed with ethanol and dried in vacuum. The orange plate-like crystals of the compound suitable for X-ray analysis were obtained by slow evaporation of the solvent within several weeks. Properties: Yield: 83\%, M.p $=225^{\circ} \mathrm{C}-227^{\circ} \mathrm{C}$. FT-IR (KBr): $\bar{v}\left(\mathrm{~cm}^{-1}\right): 3429(\mathrm{br}), 3064(\mathrm{w})$, 1929(m), 1601(s), 1561(s), 1520(w), 1476(s), 1460(s), 1435(s), 1345(s), 1296(m), 1166(s), 1096(s), 809(m), 767(s), 693(s), 654(m), 631(m). ${ }^{1} \mathrm{H}$ NMR (300 MHz, DMSO-d ${ }_{6}$ ) $\delta 8.76$ (s, 2H, ArH), 8.65 - 8.68 (d, 2H, J = 8.1 $\mathrm{Hz}, \mathrm{ArH}), 8.20$ (s, 2H, imine-H), 8.06 (s, 2H, OH), 7.57 - 7.60 (d, 4H, J = 7.3 Hz, ArH), 7.32 - 7.36 (d, 2H, J = $8.1 \mathrm{~Hz}, \mathrm{ArH}$ ), 7.19 - 7.24 (t, 4H, J = 7.3 Hz, ArH), 7.00 - 7.05 (t, 2H, J = 7.3 Hz, ArH). ${ }^{13} \mathrm{C}$ NMR, $\left(\mathrm{d}^{6}-\mathrm{DMSO}\right) \delta$, ppm: 107.3, 118.5, 122.2, 124.4, 127.7, 128.8, 130.8, 129.5, 133.7, 139.8, 157.9, 165.7 and 170.7. Elemental Anal. calc. for $\mathrm{C}_{32} \mathrm{H}_{20} \mathrm{~N}_{6} \mathrm{O}_{6} \mathrm{~S}_{4}$ : C, 53.92; H, 2.83; N, 11.79. Found: C, 53.69; H, 2.78; N, $11.69 \%$.

\subsection{Cu(II) Complex}

A copious amount of $\mathrm{CuCl}_{2} \cdot 2 \mathrm{H}_{2} \mathrm{O}$ salt $(1 \mathrm{mmol})$ was dissolved in methanol. Then, an alkaline solution of the Schiff base ligand (1) (1 mmol) in methanol was slowly added. Subsequently, reflux of the solution was continued overnight. A black precipitate was obtained from the reaction mixture. At the end, the precipitate was filtered and washed several times with methanol and then dried in vacuum. Properties: This solid decompsed at $230^{\circ} \mathrm{C}$. FT-IR (KBr): $v\left(\mathrm{~cm}^{-1}\right)$ : 3445(br), 3059(w), 2924(w), 1605(s), 1543(s), 1497(m), 1460(s), 1439(m), 1381(m), 1322(s), 1181(m), 1162(m), 1100(s), 837(m), 770(w), 694(s), 660(m), 515(w). Elemental Anal. calc. for $\mathrm{CuC}_{32} \mathrm{H}_{19} \mathrm{~N}_{6} \mathrm{O}_{6} \mathrm{~S}_{4} \mathrm{Cl}$ : C, 47.40; H, 2.36; N, 10.37. Found: C, 47.21; H, 2.38; N, 10.65\%.

\subsection{Co(II) Complex}

This complex was prepared in a manner as described above with this difference that $\mathrm{Co}\left(\mathrm{NO}_{3}\right)_{2} \cdot 6 \mathrm{H}_{2} \mathrm{O}(1 \mathrm{mmol})$ salt was used instead. After refluxing overnight, the black crystals were filtered off, washed with methanol and dried in vacuum. Properties: This solid decomposed at $265^{\circ} \mathrm{C}$. FT-IR $(\mathrm{KBr}): v\left(\mathrm{~cm}^{-1}\right)$ : 3350(br), 3059(w), 1646(m), 1602(s), 1543(s), 1479(s), 1460(s), 1439(s), 1382(m), 1319(s), 1179(s), 1130(w), 1100(s), 951(m), 838(m), 771(m), 756(m), 694(s), 656(m), 505(m). Elemental Anal. calc. for $\mathrm{CoC}_{32} \mathrm{H}_{18} \mathrm{~N}_{6} \mathrm{O}_{6} \mathrm{~S}_{4}$ : C, 49.93; H, 2.36; N, 10.92. Found: C, 49.21; H, 2.41; N, 10.89\%. To produce single crystals of this complex, the precipitate was dissolved in DMSO and the mixture kept in air to allow the solvent to evaporate. After several weeks the orange plate-like crystals were obtained by slow evaporation of the solvent. However, the X-ray analysis revealed that an unexpected Co(II) complex had been formed in which the imine bond of the Schiff base ligand had been hydrolyzed in DMSO and the product was found to be a Co(II) complex in which 5-nitro-salicylaldehyde and two DMSO molecules were coordinated to the central atom in a slightly distorted octahedral fashion.

\section{Results and Discussion}

\subsection{Crystal Structure}

The condensation reaction between bis-[2-amino-4-pheny1-5-thiazolyl] disulfide and 5-nitro-salicylaldehyde in a 1:2 molar ratio in methanol afforded the desired Schiff base (1), and its molecular structure was further investigated by single crystal X-ray diffraction. The molecular structure, together with the crystallographic numbering scheme of (1) are shown at Figure 1, with thermal ellipsoids drawn at the 50\% probability level. As shown, the molecule possesses a disulfide (-S-S-) bond and adopts a cis configuration with respect to this bond. The C10-S2-S3 and C11-S3-S2 bond angles are 101.4 (3) ${ }^{\circ}$ and 100.4 (3) ${ }^{\circ}$ which indicate the tetrahedral environments around each sulfur atom with slightly deviations. This small deviation from ideal tetrahedral angle results from the repulsion between lone pairs on the sulfur atoms. The dihedral angle of C10-S2-S3-C11 is -58.5 (4) ${ }^{\circ}$ which indicates that it is twisted around the disulfide bond. In comparison to the average $\mathrm{S}-\mathrm{S}$ bond length reported for similar structures (2.02 $\pm 0.03 \AA$ ) [41]-[44], the S-S bond in this present Schiff base is somewhat elongated at 2.112 (3) $\AA$ (see Table 2). For example, Schroth et al., have synthesized two compounds with $\mathrm{S}-\mathrm{S}$ 


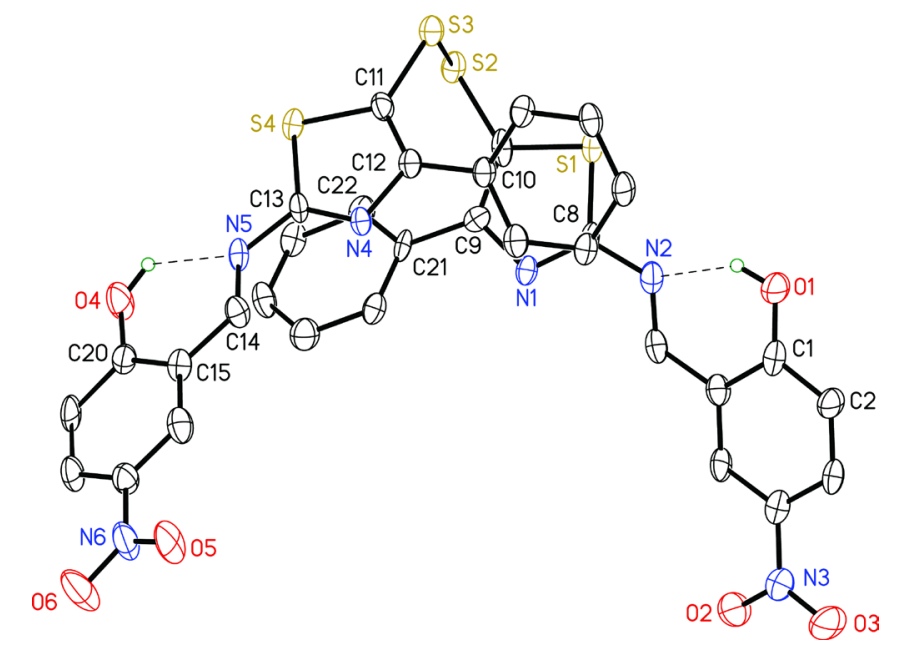

Figure 1. The molecular structure together with the crystallographic numbering of (1), with thermal ellipsoids drawn at 50\% probability level.

Table 2. Selected bond distances $(\AA)$ and angles $\left(^{\circ}\right)$ for compounds (1) and (2).

\begin{tabular}{|c|c|c|c|}
\hline Compound (1) & & & \\
\hline S2-S3 & $2.112(3)$ & N1-C8 & $1.303(11)$ \\
\hline S1-C8 & $1.719(8)$ & N1-C9 & $1.361(10)$ \\
\hline S1-C10 & $1.735(8)$ & N2-C7 & $1.281(11)$ \\
\hline S2-C10 & $1.742(8)$ & N2-C8 & $1.394(11)$ \\
\hline S3-C11 & $1.757(7)$ & N3-O2 & $1.226(11)$ \\
\hline S4-C11 & $1.730(8)$ & N3-O3 & $1.247(10)$ \\
\hline S4-C13 & $1.723(7)$ & $\mathrm{C} 1-\mathrm{O} 1$ & $1.307(11)$ \\
\hline $\mathrm{N} 4-\mathrm{C} 12$ & $1.390(10)$ & C20-O4 & $1.336(10)$ \\
\hline N4-C13 & $1.299(11)$ & C9-C10 & $1.375(11)$ \\
\hline N5-C13 & $1.391(10)$ & C11-C12 & $1.363(12)$ \\
\hline N5-C14 & $1.296(10)$ & C9-C21 & $1.480(12)$ \\
\hline N6-O5 & $1.240(11)$ & C12-C27 & $1.481(12)$ \\
\hline N6-O6 & $1.235(11)$ & & \\
\hline C8-S1-C10 & $88.8(4)$ & C8-N1-C9 & $111.0(6)$ \\
\hline S3-S2-C10 & $101.4(3)$ & C7-N2-C8 & $117.4(7)$ \\
\hline S2-S3-C11 & $100.4(3)$ & O2-N3-O3 & $122.8(8)$ \\
\hline C11-S4-C13 & $88.1(4)$ & C12-N4-C13 & $110.8(6)$ \\
\hline O5-N6-O6 & $121.8(8)$ & C13-N5-C14 & $118.7(7)$ \\
\hline N4-C12-C27-C28 & $31.7(10)$ & C10-C9-C21-C22 & $34.1(12)$ \\
\hline C6-C7-N2-C8 & $-177.1(7)$ & N1-C9-C21-C26 & $31.6(10)$ \\
\hline C13-N5-C14-C15 & $-174.6(7)$ & C11-C12-C27-C32 & $34.2(12)$ \\
\hline \multicolumn{4}{|l|}{ Compound (2) } \\
\hline Co1-O3 & $2.0124(17)$ & O1-N1 & $1.230(3)$ \\
\hline Co1-O4 & $2.1015(18)$ & $\mathrm{O} 2-\mathrm{N} 1$ & 1.236 (3) \\
\hline Co1-O5 & $2.1234(18)$ & O3-C1 & $1.282(3)$ \\
\hline $\mathrm{S} 1-\mathrm{O} 5$ & $1.5263(19)$ & $\mathrm{O} 4-\mathrm{C} 7$ & $1.235(3)$ \\
\hline S1-C9 & $1.774(3)$ & N1-C4 & $1.448(3)$ \\
\hline \multirow[t]{2}{*}{ S1-C8 } & $1.777(3)$ & & \\
\hline & & $\mathrm{O}^{\# 1}-\mathrm{C} 01-\mathrm{O} 3$ & 180.0 \\
\hline O3-Co1-O5 & $90.74(7)$ & $\mathrm{O} 4^{\# 1-C o 1-O 4}$ & 180.0 \\
\hline O3-Co1-O4 & $88.40(7)$ & $\mathrm{O5}^{\# 1-C o 1-O 5}$ & 180.0 \\
\hline O3-Co1-O4 ${ }^{\# 1}$ & $91.60(7)$ & $\mathrm{O} 4-\mathrm{Co} 1-\mathrm{O} 5^{\# 1}$ & $94.00(8)$ \\
\hline O3-Co1-O5 & $89.26(7)$ & O4-Co1-O5 & $86.00(8)$ \\
\hline
\end{tabular}

Symmetry code $(\# 1):-x+1,-y+1,-z+1$. 
bond distances of $2.061 \AA$ and $2.067 \AA$ [43]. Also in a disulfide-linked Schiff base prepared by Donzelli et al., a value of 2.064 (2) $\AA$ is reported for a similar bond [45]. The C10-S2 and C11-S3 bond distances are 1.742 (8) $\AA$ and 1.757 (7) $\AA$, and the lengths of two C7-N2 and C14-N5 imine bonds are 1.281 (11) $\AA$ and 1.296 (10) $\AA$. Also, the four C22-C21-C9-N1, C26-C21-C9-C10, C28-C27-C12-N4 and C32-C27-C12-C11 dihedral angles are $-145.5(7)^{\circ},-148.8(8)^{\circ}, 31.7(10)^{\circ}$ and $34.2(12)^{\circ}$, respectively, indicate that pendant phenyl groups and thiazole rings are not located in the same planes. Furthermore, the C8-S1-C10 and C11-S4-C13 angles are smaller than that of 2-amino-4-phenylthiazole hydrobromide monohydrate [88.8 (4) and 88.1 (4) vs. $90.17^{\circ}$ ] [46]. The exocyclic, [C7-N1, C8-N1, C13-N4 and C14-N4], and heterocyclic, [C8-N2, C9-N2, C12-N3 and C13-N3] bond distances are listed in Table 2, in which are in excellent agreement with Fehlmann's data [47]. It was expected that the $\mathrm{C}-\mathrm{N}$ bond distances would be dissimilar as a consequence of different bond order between these atoms. The C9-C21 and C12-C27 bond distances in (1) are 1.480 (12) $\AA$ and 1.481 (12) $\AA$. Compared with the value of $1.506 \AA$ found in 2-amino-4-phenylthiazole hydrobromide monohydrate; there is a greater double-bond character of the corresponding bonds in (1). Also, the inter-ring distances of C9-C10 and C11-C12 are 1.375 (11) $\AA$ and 1.363 (12) $\AA$. The angles of $88.8(4)^{\circ}$ and $88.1(4)^{\circ}$ at the heterocyclic sulfur atoms [C8-S1-C10 and C11-S4-C13] are common for substituted thiazole molecules. As shown in Table 3, the structure of (1) contains two distinct intramolecular hydrogen bond between the hydrogen atom of the phenolic group and the nitrogen atom of imine fragment, O1-H1 $\cdots \mathrm{N} 2$ and $\mathrm{O} 4-\mathrm{H} 4 \cdots \mathrm{N} 5$ with $\mathrm{D} \cdots \mathrm{A}$ distances of 2.636 (10) $\AA$ and 2.576 (9) $\AA$.

As mentioned, we started our investigation to synthesize a complex of Co(II) with the potentially tetradentate $\mathrm{N}_{2} \mathrm{O}_{2}$ Schiff base (1). However, recrystallization in DMSO in the presence of trace water from the cobalt salt, caused complete hydrolysis of the Schiff base. Subsequent coordination of the resultant 5-nitro-salicylaldehyde with $\mathrm{Co}(\mathrm{II})$ ion occurs with the formation of the $\left[\mathrm{Co}\left(\mathrm{NO}_{2}-\mathrm{sal}\right)_{2}(\mathrm{DMSO})_{2}\right]$ complex (Scheme 1). It is well known that the characteristic bond of the Schiff bases, $\mathrm{C}=\mathrm{N}$, has reversible nature which allows by hydrolysis, obtaining the initial corresponding aldehyde and amine compounds [48] [49]. It seems that the presence of the metal cations accelerates the hydrolysis of the imine bond regenerating the starting materials. X-ray single crystal diffraction study reveals that the crystal structure of the reaction product consists of neutral octahedral units shown in Figure 2. The Co(II) complex lies on center of inversion and the octahedral environment of $\mathrm{Co}(\mathrm{II})$ ion is formed by the four oxygen atoms of 5-nitro-salicylaldehyde moiety and two molecules of DMSO in the apical positions.

The 5-nitro-salicylaldehyde ligands coordinate in a typical mode through the phenolate and carbonyl oxygen atoms, forming six-membered chelate rings with the bite angles of $88.40(7)^{\circ}$. The $\mathrm{Co}-\mathrm{O}$ bond lengths formed by phenolate and carbonyl oxygen atoms [Co1-O3 = 2.0124 (17) $\AA$ and Co1-O4 = 2.1015 (18) $\AA$ ] are shorter than those of Co-O bonds from DMSO molecules [Co1-O5 = 2.1234 (18) $\AA$ ].

Numerous complexes are known in which 5-nitro-salicylaldehyde ligand has coordinated to the central atom. Papadopoulos et al., have reported syntheses and X-ray structures of a few $\mathrm{Co}$ (II) complexes [50] in which the metal cations were bonded to two deprotonated 5-nitro-salicycaldehyde ligands and one phenanthroline or neocuproine ligand to fulfill its octahedral coordination sphere. In our sample, each substituted salicylaldehyde

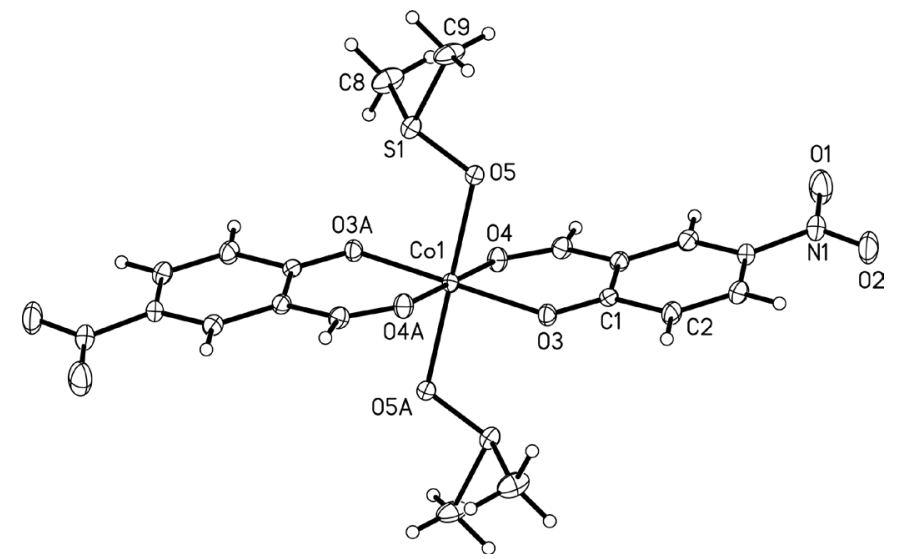

Figure 2. The molecular structure together with the crystallographic numbering of (2), with thermal ellipsoids drawn at 50\% probability level. 
Table 3. Hydrogen bonding parameters $\left(\AA,^{\circ}\right)$ for compounds (1) and (2).

\begin{tabular}{|c|c|c|c|c|}
\hline D-H $\cdots A$ & d (D-H) & d $(\mathrm{H} \cdots A)$ & $d(D \cdots A)$ & $<(\mathrm{D}-\mathrm{H} \cdots \mathrm{A})$ \\
\hline \multicolumn{5}{|l|}{ Compound (1) } \\
\hline $\mathrm{O} 1-\mathrm{H} 1 \cdots \mathrm{N} 2$ & 0.84 & 1.90 & $2.606(10)$ & 141 \\
\hline $\mathrm{O} 4-\mathrm{H} 4 \cdots \mathrm{N} 5$ & 0.85 & 2.05 & $2.576(9)$ & 120 \\
\hline $\mathrm{C} 2-\mathrm{H} 2 \cdots \mathrm{O}^{\# 1}$ & 0.95 & 2.50 & $3.226(11)$ & 134 \\
\hline $\mathrm{C} 22-\mathrm{H} 22 \cdots \mathrm{S} 2$ & 0.95 & 2.80 & 3.323 (9) & 116 \\
\hline 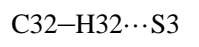 & 0.95 & 2.79 & 3.307 (8) & 116 \\
\hline \multicolumn{5}{|l|}{ Compound (2) } \\
\hline $\mathrm{C} 7-\mathrm{H} 7 \cdots \mathrm{O}^{\# 2}$ & 0.95 & 2.55 & 3.349 (3) & 141 \\
\hline $\mathrm{C} 9-\mathrm{H} 9 \mathrm{C} \cdots \mathrm{O} 5^{\# 3}$ & 0.98 & 2.37 & $3.349(4)$ & 174 \\
\hline
\end{tabular}

Symmetry codes: (\#1) 1-x, -y, $1-z$; (\#2) x, 1/2-y, 1/2 + z; (\#3) 1-x, 1-y, -z.

ligand was coordinated through the deprotonated phenolic oxygen atom and through the carbonyl oxygen. The reported Co-O bond distances range from 2.0202 (2) $\AA$ to 2.140 (1) $\AA$ and are in good agreement with those found in our structure. In addition, Tangoulis et al., has recently published a work in which single chain magnets of Co(II) are formed by using 5-nitro-salicycaldehyde as ligand [51].

\subsection{FT-IR Study}

The main characteristic of the FT-IR spectrum of Schiff base (1), is disappearance of the absorption bands of $-\mathrm{NH}_{2}\left(3420 \mathrm{~cm}^{-1}\right)$ and carbonyl $\left(1665 \mathrm{~cm}^{-1}\right)$ fragments from starting materials i.e., bis-[2-amino-4-pheny1-5thiazolyl] disulfide and 5-nitro-salicycaldehyde and in return, appearance of the stretching of azomethine group, $v(\mathrm{C}=\mathrm{N})$, at $1561 \mathrm{~cm}^{-1}$ which changes upon coordination of the ligand to the metal atoms. The stretching of $\mathrm{OH}$ phenolic group appears at $3429 \mathrm{~cm}^{-1}$. In addition, the band near $1345 \mathrm{~cm}^{-1}$ is assigned to $v(\mathrm{C}-\mathrm{O})$ stretching of the phenolic group. Although the absorption of $v(\mathrm{C}=\mathrm{C})$ band does not change from the free ligand to the $\mathrm{Co}(\mathrm{II})$ and $\mathrm{Cu}(\mathrm{II})$ complexes, the downfield shift of the $v(\mathrm{C}=\mathrm{N})$ vibration $\left(1543 \mathrm{~cm}^{-1}\right)$ suggests that the nitrogen atom of imine group participates in coordination to the $\mathrm{Co}(\mathrm{II})$ and $\mathrm{Cu}(\mathrm{II})$ atoms, respectively.

\subsection{NMR Study}

In the ${ }^{1} \mathrm{H}$ NMR spectra of 2-amino-4-phenylthiazole, the signal at $7.21 \mathrm{ppm}$ is assigned to the amino groups. The protons of the pendant phenyl ring are also observed at 7.23 - 7.80 ppm and the hydrogen atom of thiazole ring appears at $6.98 \mathrm{ppm}$. In the ${ }^{1} \mathrm{H}$ NMR spectrum of the bis-[2-amino-4-pheny1-5-thiazolyl] disulfide, the signal at $7.69 \mathrm{ppm}$ is assigned to the amino groups and protons of the aromatic ring are also observed at $7.23-7.80 \mathrm{ppm}$. In 5-nitro-salicylaldehyde, the signal at $\delta 11.96 \mathrm{ppm}$ is assigned to the proton of the $\mathrm{OH}$ group and the signal for CHO fragments appears at $10.22 \mathrm{ppm}$. In (1), the broad signal at $\delta 12.52 \mathrm{ppm}$ is assigned to the proton of the $\mathrm{OH}$ group. It was observed that this signal completely disappears when adding $\mathrm{D}_{2} \mathrm{O}$. The single proton of $-\mathrm{CH}=\mathrm{N}$ has chemical shift at $\delta 9.18 \mathrm{ppm}$ and signals around $\delta 7.00-8.80 \mathrm{ppm}$ are attributed to the protons of aromatic rings. In the ${ }^{13} \mathrm{C}$ NMR spectrum, the carbon atoms of $-\mathrm{CH}=\mathrm{N}$ and $\mathrm{C}-\mathrm{O}$ groups show resonances at 170.7 and $157.9 \mathrm{ppm}$, respectively. The remaining carbon atoms of the aromatic rings have signals that range from 107.3 to $139.8 \mathrm{ppm}$. As both complexes are paramagnetic and exhibit broad ${ }^{1} \mathrm{H}$ NMR signals, no further analysis can be performed.

\subsection{UV-Vis Studies}

The electronic absorption spectral bands of the Schiff base, $\mathrm{Cu}(\mathrm{II})$ and Co(II) complexes were recorded over the range $200-600 \mathrm{~nm}$ in DMSO. The electronic spectrum of the Schiff base ligand shows two absorption bands at 372 and $426 \mathrm{~nm}$. The short-wave band may be attributed to electron transitions in the aromatic rings (intra ligand (IL) $n-\pi^{*}$ ), and the longer wavelength band at $426 \mathrm{~nm}$ is assigned to the $\pi-\pi^{*}$ transition in the azomethine chromospheres in the Schiff base ligand [52]. The $\mathrm{Cu}(\mathrm{II})$ complex displays absorption bands at $364 \mathrm{~nm}$ and 420 
nm, respectively. Also, the Co(II) complex displays absorption bands at $365 \mathrm{~nm}$ and $429 \mathrm{~nm}$.

\subsection{Solution Studies}

In this study, we also report further investigation of the $\mathrm{Cu}(\mathrm{II})$ and $\mathrm{Co}(\mathrm{II})$ complexes. It is important to note that the method used in this research has some advantages over the Jobs analysis. In fact, a limited number of samples (10 samples for instance) with different volume ratios should be prepared in Jobs analysis. However, in the UV-Vis titration the desired amount of metal $\left(5 \times 10^{-3} \mathrm{M}\right)$ is added to the ligand solution $\left(5.0 \times 10^{-5} \mathrm{M}\right)$ in one cell and then this addition continues up to 30 times. The absorbance spectrum of the mixture is recorded after each addition. Therefore, the numbers of obtained points are higher in this method and the accuracy would definitely be better. In a typical procedure, $2.0 \mathrm{~mL}$ of ligand solution in methanol is placed in the spectrophotometer cell and the absorbance of the solution is measured. Then an appropriate amount of $\mathrm{CuCl}_{2}$ or $\mathrm{Co}\left(\mathrm{NO}_{3}\right)_{2}$ in methanol is added in a stepwise manner using a $2-\mu$ l Hamilton syringe. The absorbance spectrum of the solution is recorded after each addition. The $\mathrm{Cu}(\mathrm{II})$ and $\mathrm{Co}(\mathrm{II})$ solutions were continually added until the desired metal to ligand mole ratio was achieved. The electronic absorption spectra of the Schiff base ligand (1) in the presence of increasing concentration of $\mathrm{CuCl}_{2}$ and $\mathrm{Co}\left(\mathrm{NO}_{3}\right)_{2}$ in $\mathrm{MeOH}$ at room temperature is shown in Figure 3 and Figure 4 , respectively. The resulting absorbance against $[\mathbf{L}] /\left[\mathrm{M}^{2+}\right]\left(\mathrm{M}^{2+}: \mathrm{Cu}(\mathrm{II}), \mathrm{Co}(\mathrm{II})\right)$ mole ratio plot is shown in the inset of each figure. As mentioned, the injection point at ligand-to-metal molar ratio of about1 indicates the formation of ML compound with mole ratio of 1:1.

\section{Conclusion}

In continuation of recently published papers regarding bithiazole-containing materials [53] [54], in this study, we synthesized and characterized a novel Schiff base ligand from a bis-[2-amino-4-phenyl-5-thiazolyl] disulfide template (1). The $[\mathrm{CoL}]$ and $[\mathrm{ClCuHL}]$ complexes of the ligand were prepared and the products were further investigated by UV-Vis that confirmed the formation of desired complex in a 1:1 molar ratio. Using DMSO as recrystallization solvent caused the complete hydrolysis of the imine bond and afforded a $\mathrm{Co}(\mathrm{II})$ (2) complex in which two 5-nitro-salicylaldehyde and two solvent molecules were coordinated to the Co(II) atom in a octahedral fashion. The solid state structures of both (1) and (2) were further substantiated by single crystal X-ray diffraction.

\section{Acknowledgements}

J. A. thanks M. M. Olmstead of the Department of Chemistry, University of California, Davis, for experimental

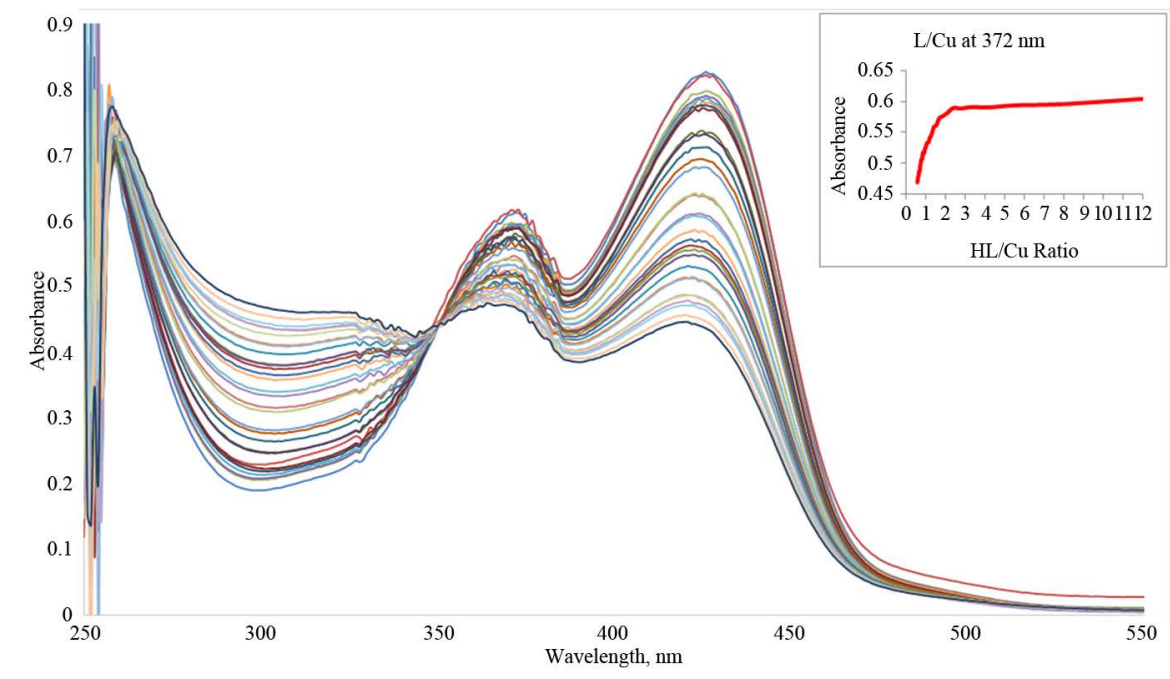

Figure 3. Electronic absorption spectra of the ligand (1) in $\mathrm{MeOH}$ in the presence of increasing concentration of $\mathrm{CuCl}_{2}$ at room temperature. (b) Corresponding mole ratio plot of $\mathrm{L} / \mathrm{Cu}(\mathrm{II})$. 


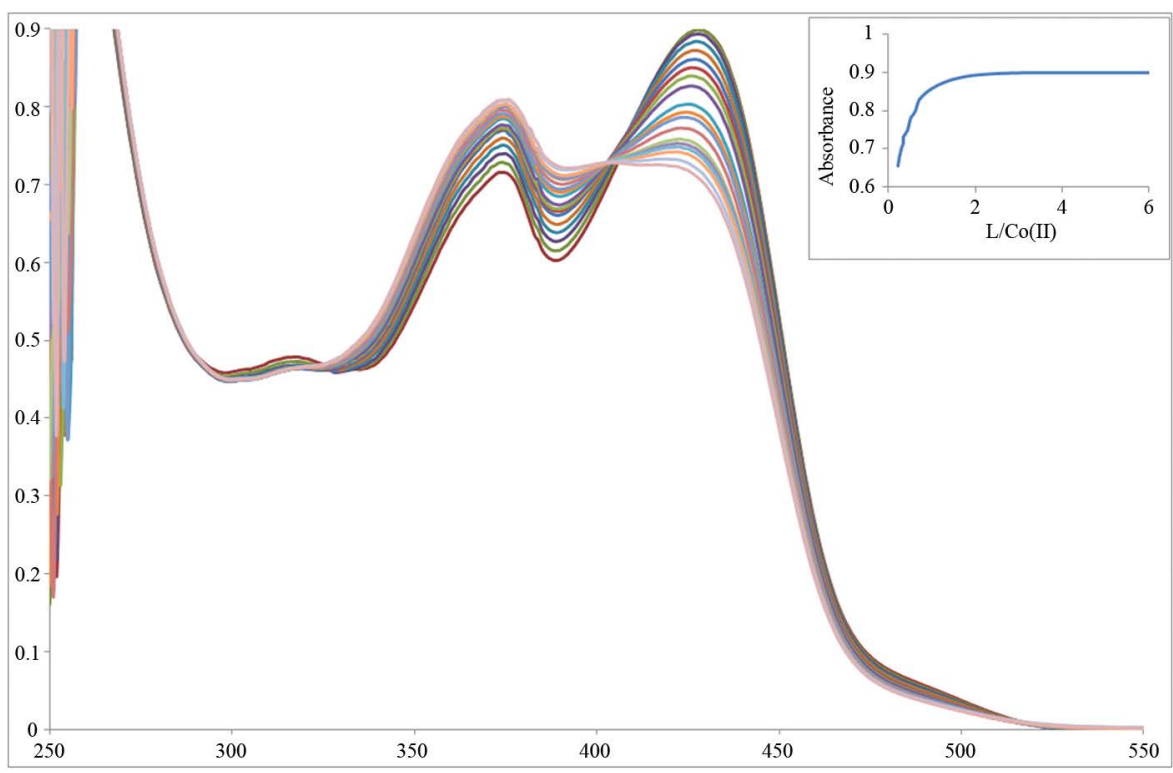

Figure 4. (a) Electronic absorption spectra of the ligand (1) in $\mathrm{MeOH}$ in the presence of increasing concentration of $\mathrm{Co}\left(\mathrm{NO}_{3}\right)_{2}$ at room temperature. (b) Corresponding mole ratio plot of $\mathrm{L} / \mathrm{Co}(\mathrm{II})$.

assistance with X-ray data collection and structure solution. We also thank the Advanced Light Source, supported by the Director, Office of Science, Office of Basic Energy Sciences, of the U.S. Department of Energy under Contract DE-AC02-05CH11231, for beam time and a fellowship to K.B.G.

\section{References}

[1] Khouba, Z., Benabdallah, T. and Maschke, U. (2009) Spectrophotometric Study of Liquid Crystals Containing Pentadentate Schiff Base Type Systems. Physics Procedia, 2, 1305-1311. http://dx.doi.org/10.1016/j.phpro.2009.11.096

[2] Zhang, L.X., Liu, Y., Cia, L.H., Hu, Y.J., Yin, J. and Hu, P.Z. (2006) Inhibitory Study of Some Novel Schiff Base Derivatives on Staphylococcus aureus by Microcalorimetry. Thermochimica Acta, 440, 51-56. http://dx.doi.org/10.1016/j.tca.2005.10.012

[3] Losada, J., Del Peso, I. and Beyer, L. (2001) Electrochemical and Spectroelectrochemical Properties of Copper(II) Schiff-Base Complexes. Inorganica Chimica Acta, 321, 107-115. http://dx.doi.org/10.1016/S0020-1693(01)00511-4

[4] Santos, M.L.P., Bagatin, I.A., Pereira, E.M. and Ferreira, A.M.D.C. (2001) Redox Behaviour and Reactivity of Di-Schiff Base-Copper(II) Complexes toward Reduced Oxygen Species. Journal of the Chemical Society, Dalton Transactions, Issue 6, 838-844. http://dx.doi.org/10.1039/b004985i

[5] Tatar Yildirim, L., Emregul, K., Kurtaran, R. and Atakol, O. (2002) Structure and Electrochemical Behaviour of Bis [N-(4-methylphenyl)salicylaldimine] Copper(II) N, N’Dimethylformamide Solvate. Crystal Research and Technology, 37, 1344-1351. http://dx.doi.org/10.1002/crat.200290012

[6] Liu, C.M., Xiong, R.G., You, X.Z., Liu, Y.J. and Cheung, K.K. (1996) Crystal Structure and Some Properties of a Novel Potent $\mathrm{Cu}_{2} \mathrm{Zn}_{2} \mathrm{SOD}$ Model Schiff Base Copper(II) Complex. Polyhedron, 15, 4565-4571. http://dx.doi.org/10.1016/0277-5387(96)00163-5

[7] Mohamed, G.G., Omar, M.M. and Hindy, A.M.M. (2005) Synthesis, Characterization and Biological Activity of Some Transition Metals with Schiff Base derived from 2-Thiophene Carboxaldehyde and Aminobenzoic Acid. Spectrochimica Acta A, 62, 1140-1150. http://dx.doi.org/10.1016/j.saa.2005.03.031

[8] Mohamed, G.G., Zayed, M.A. and Abdallah, S.M. (2010) Metal Complexes of a Novel Schiff Base Derived from Sulphametrole and Varelaldehyde. Synthesis, Spectral, Thermal Characterization and Biological Activity. Journal of Molecular Structure, 979, 62-71. http://dx.doi.org/10.1016/j.molstruc.2010.06.002

[9] Basak, S., Sen, S., Banerjee, S., Mitra, S., Rosair, G. and Rodriguez, M.G. (2007) Three New Pseudohalide Bridged Dinuclear Zn(II) Schiff Base Complexes: Synthesis, Crystal Structures and Fluorescence Studies. Polyhedron, 26, 5104-5112. http://dx.doi.org/10.1016/j.poly.2007.07.025

[10] Gupta, K.C. and Sutar, A.K. (2008) Catalytic Activities of Schiff Base Transition Metal Complexes. Coordination 
Chemistry Reviews, 252, 1420-1450. http://dx.doi.org/10.1016/j.ccr.2007.09.005

[11] Taggi, A.E., Hafez, A.M., Wack, H., Young, B., Ferraris, D. and Lectka, T. (2002) The Development of the First Catalyzed Reaction of Ketenes and Imines: Catalytic, Asymmetric Synthesis of Beta-Lactams. Journal of the American Chemical Society, 124, 6626-6635. http://dx.doi.org/10.1021/ja0258226

[12] Venturini, A. and González, J. (2002) A CASPT2 and CASSCF Approach to the Cycloaddition of Ketene and Imine: A New Mechanistic Scheme of the Staudinger Reaction. The Journal of Organic Chemistry, 67, 9089-9092. http://dx.doi.org/10.1021/jo026188h

[13] Delpiccolo, C.M. and Mata, E.G. (2002) Stereoselective Solid-Phase Synthesis of 3,4-Substituted Azetidinones as Key Intermediates for Mono- and Multicyclic $\beta$-Lactam Antibiotics and Enzyme Inhibitors. Tetrahedron: Asymmetry, 13, 905-910. http://dx.doi.org/10.1016/S0957-4166(02)00214-8

[14] More, P., Bhalvankar, R.B. and Pattar, S.C.J. (2001) Synthesis and Biological Activities of Schiff Bases of Aminothiazoles. Indian Chemical Society, 78, 474-475.

[15] Basser, M.A. and Mote, N.A. (2001) Synthesis and Antimicrobial Activity of Some Schiff Bases from Benzothiazoles. Asian Journal of Chemistry, 13, 496-500.

[16] Neelakantan, M.A., Rusalraj, F., Dharmaraja, J., Johnsonraja, S., Jeyakumar, T. and Pillai, M.S. (2008) Spectral Characterization, Cyclic Voltammetry, Morphology, Biological Activities and DNA Cleaving Studies of Amino Acid Schiff Base Metal(II) Complexes. Spectrochimica Acta A, 71, 1599-1609. http://dx.doi.org/10.1016/j.saa.2008.06.008

[17] Prashanthi, Y., Kiranmai, K., Subhashini, N.J.P. and Shivaraj, S. (2008) Synthesis, Potentiometric and Antimicrobial Studies on Metal Complexes of Isoxazole Schiff Bases. Spectrochimica Acta A, 70, 30-35. http://dx.doi.org/10.1016/j.saa.2007.07.028

[18] Babasaheb, P.B., Shrikant, S.G., Ragini, G.B., Jalinder, V.T. and Chandrahas, N.K. (2010) Synthesis and Biological Evaluation of Simple Methoxylated Chalcones as Anticancer, Anti-Inflammatory and Antioxidant Agents. Bioorganic and Medicinal Chemistry, 18, 1364-1370. http://dx.doi.org/10.1016/j.bmc.2009.11.066

[19] Zhang, N., Fan, Y., Zhang, Z., Zuo, J., Zhang, P., Wang, Q., Liu, S.B. and Bi, C.F. (2012) Syntheses, Crystal Structures and Anticancer Activities of Three Novel Transition Metal Complexes with Schiff Base Derived from 2-Acetylpyridine and l-Tryptophan. Inorganic Chemistry Communications, 22, 68-72. http://dx.doi.org/10.1016/j.inoche.2012.05.022

[20] Hajrezaie, M., Hassandarvish, P., Moghadamtousi, S.Z., Gwaram, N.S., Golbabapour, S., NajiHussien, A., Almagrami, A.A., Zahedifard, M., Rouhollahi, E., Karimian, H., Fani, S., Kamalidehghan, B., Majid, N.A., Ali, H.M. and Abdulla, M.A. (2014) A Schiff Base-Derived Copper (II) Complex Is a Potent Inducer of Apoptosis in Colon Cancer Cells by Activating the Intrinsic Pathway. The Scientific World Journal, 2014, Article ID: 540463. http://dx.doi.org/10.1155/2014/540463

[21] Chen, X., Femia, F.J., Babich, J.W. and Zubieta, J. (2000) The Syntheses and Structures of “3+2" and “2+2+1" Oxorhenium Mixed-Ligand Complexes Employing 8-Hydroxy-5-Nitroquinoline as the Bidentate N,O Donor Ligand. Inorganica Chimica Acta, 308, 80-90. http://dx.doi.org/10.1016/S0020-1693(00)00218-8

[22] Mimuro, M., Hirayama, K., Uezono, K., Miyashita, H. and Miyachi, S. (2000) Uphill Energy Transfer in a Chlorophyll D-Dominating Oxygenic Photosynthetic Prokaryote, Acaryochloris Marina. Biochimica et Biophysica Acta (BBA), 1456, 27-34. http://dx.doi.org/10.1016/S0005-2728(99)00095-X

[23] Teoh, S.G., Yeap, G.Y., Loh, C.C., Foong, L.W., Teo, S.B. and Fun, H.K. (1997) Inner Coordination Sphere tin(IV) Complexes with Some O,N,N-terdentate\{N-(2-hydroxybenzaldehyde)-1-amino-2-phenyleneimine and N-(2-hydroxy1-naphthaldehyde)-1-amino-2-phenyleneimine $\}$ and O,N,N,O-quadridentate\{N,N'-bis(2-hydroxyben-zaldehyde)-1,2phenylenediimine and N,N'-bis(2-hydroxy-1-naphthaldehyde)-1,2-phenylenediimine\} Schiff Bases. Polyhedron, 16, 2213-2221. http://dx.doi.org/10.1016/S0277-5387(96)00546-3

[24] Bu, X.R., Jackson, C.R., Van Derveer, D., You, X.Z., Meng, Q.J. and Wang, R.X. (1997) New Copper(II) Complexes Incorporating Unsymmetrical Tetradentate Ligands with cis- $\mathrm{N}_{2} \mathrm{O}_{2}$ Chrmophores-Synthesis, Molecular-Structure, Substitut Effect and Thermal-Stability. Polyhedron, 16, 2991-3001. http://dx.doi.org/10.1016/S0277-5387(97)00048-X

[25] Gourbatsis, S., Perlepes, S.P., Butler, I.S. and Hadjiliadis, N. (1999) Zinc(II) Complexes Derived from the di-Schiff-Base Ligand N,N'-bis[1(pyridin-2-yl)ethylidene]ethane-1,2-diamine $\left(\mathrm{L}_{\mathrm{A}}\right)$ and Its Hydrolytic-Cleavage Product N-[1-pyridin-2-yl)ethylidene]ethane-1,2-diamine (L): Preparation, Characterization and Crystal Structure of the 5-Coordinate Species [ZnLCl ${ }_{2}$. Polyhedron, 18, 2369-2375. http://dx.doi.org/10.1016/S0277-5387(99)00141-2

[26] Pietzsch, H.J., Spies, H., Hoffmann, S. and Stach, J. (1989) Lipophilic Technetium Complexes. V. Synthesis and Characterization of (3-thiapentane-1,5-dithiolato) (thiophenolato)oxotechnetium(V). Inorganica Chimica Acta, 161, 15-16. http://dx.doi.org/10.1016/S0020-1693(00)90107-5

[27] Cano, J., Benito, A., Martínez-Máñez, R., Soto, J., Payá, J., Lloret, F., Julve, M., Marcos, M.D. and Sinn, E. (1995) Ferrocene Containing Chelating Ligands. 3. Synthesis, Spectroscopic Characterization, Electrochemical-Behavior and 
Interaction with Metal Ions of New Ligands Obtained by Condensation of Ferrocenecarboxaldehyde with 2-aminobenzoic Acid-Derivatives. Inorganica Chimica Acta, 231, 45-56. http://dx.doi.org/10.1016/0020-1693(94)04318-P

[28] Mukherjee, P., Drew, M.G.B. and Ghosh, A. (2008) Anion-Directed Template Synthesis and Hydrolysis of Mono-Condensed Schiff Base of 1,3-Pentanediamine and o-Hydroxyacetophenone in $\mathrm{Ni}^{\mathrm{II}}$ and $\mathrm{Cu}^{\mathrm{II}}$ Complexes. European Journal of Inorganic Chemistry, 2008, 3372-3381. http://dx.doi.org/10.1002/ejic.200800186

[29] Dong, Y.B., Zhao, X., Hung, R.Q., Smith, M.D. and zur Loye, H.C. (2004) New Ag(I)-Containing Coordination Polymers Generated from Multidentate Schiff-Base Ligands. Inorganic Chemistry, 43, 5603-5612. http://dx.doi.org/10.1021/ic049787a

[30] Mandal, D., Bertolasi, V., Ribas-Ariño, J., Aromí, G. and Ray, D. (2008) Self-Assembly of an Azido-Bridged [NiII6] Cluster Featuring Four Fused Defective Cubanes. Inorganic Chemistry, 47, 3465-3467. http://dx.doi.org/10.1021/ic800188j

[31] Sarkar, B., Ray, M.S., Drew, M.G.B., Figuerola, A., Diaz, C. and Ghosh, A. (2006) Trinuclear Cu(II) Complexes Containing Peripheral Ketonic Oxygen Bridges and a $\mu 3-\mathrm{OH}$ Core: Steric Influence on Their Structures and Existence. Polyhedron, 25, 3084-3094. http://dx.doi.org/10.1016/j.poly.2006.05.032

[32] Chattopadhyay, S., Drew, M.G.B. and Ghosh, A. (2007) Anion Directed Templated Synthesis of Mono- and di-Schiff Base Complexes of Ni (II). Polyhedron, 26, 3513-3522. http://dx.doi.org/10.1016/j.poly.2007.03.037

[33] Chattopadhyay, S., Chakraborty, P., Drew, M.G.B. and Ghosh, A. (2009) Nickel(II) Complexes of Terdentate or Symmetrical Tetradentate Schiff Bases: Evidence of the Influence of the Counter Anions in the Hydrolysis of the Imine Bond in Schiff Base Complexes. Inorganica Chimica Acta, 362, 502-508. http://dx.doi.org/10.1016/j.ica.2008.05.004

[34] Naiya, S., Sarkar, B., Song, Y., Ianelli, S., Drew, M.G.B. and Ghosh, A. (2010) Carbonyl Compound Dependent Hydrolysis of Mono-Condensed Schiff Bases: A Trinuclear Schiff Base Complex and a Mononuclear Mixed-Ligand Ternary Complex of Copper(II). Inorganica Chimica Acta, 363, 2488-2495. http://dx.doi.org/10.1016/j.ica.2010.04.010

[35] Dodson, R.M. and Carroll King, L. (1945) The Reaction of Ketones with Halogens and Thiourea. Journal of the American Chemical Society, 67, 2242-2243. http://dx.doi.org/10.1021/ja01228a059

[36] Bruker (2014) APEX2, SAINT, TWINABS. Bruker AXS Inc., Madison.

[37] Sheldrick, G.M. (2008) A Short History of SHELX. Acta Crystallographica A, A64, 112-122. http://dx.doi.org/10.1107/S0108767307043930

[38] Sheldrick, G.M. (2015) Crystal Structure Refinement with SHELXL. Acta Crystallographica C, C71, 3-8. http://dx.doi.org/10.1107/S2053229614024218

[39] Woodbridge, R.G. and Dougherty, G. (1949) A Novel Sulfidation Reaction and Its Application to Some 4-Substituted2-aminothiazoles. Journal of the American Chemical Society, 71, 1744-1745. http://dx.doi.org/10.1021/ja01173a057

[40] Panchabhai, V.B., Budhwani, S.N., Jagtab, S.S., Zambare, Y.B. and Kalyane, N.Y. (2011) Synthesis and Biological Evaluation of Some Novel Benzofuran Containing Carbamide Derivatives. Asian Journal of Pharmaceutical and Health Sciences, 1, 158-162.

[41] Wang, D., Behrens, A., Farahbakhsh, M., Gatjens, J. and Rehder, D. (2003) Formation, Preservation, and Cleavage of the Disulfide Bond by Vanadium. Chemistry—A European Journal, 9, 1805-1813. http://dx.doi.org/10.1002/chem.200390207

[42] Okamatsu, T., Irie, R. and Katsuki, T. (2007) Unique Tripodal Chiral Tertiary Amine, 2,6-trans-1,2,6-trisubstituted Piperidine with Pyridine and bis(phenol) Donor Groups: Its Stereoselective Coordination to Titanium(IV) Ion. Journal of Organometallic Chemistry, 692, 645-653. http://dx.doi.org/10.1016/j.jorganchem.2006.07.045

[43] Schroth, W., Hintzsche, E., Jordan, H., Jende, T., Spitzner, R. and Thondorf, I. (1997) 1,2-Dithiins and Precursors, XVII1: Synthesis and Properties of Thieno Anellated 1,2-Dithiins, Structural Influence on Colour. Tetrahedron, 53, 7509-7528. http://dx.doi.org/10.1016/S0040-4020(97)00439-0

[44] Wang, Y., Shi, S., Han, Y. and Wei, G.D. (2011) Bis[2-(benzyl-idene-amino)-phen-yl] Disulfide. Acta Crystallographica E, E67, o3364. http://dx.doi.org/10.1107/S1600536811048239

[45] Donzelli, A., Metushi, I. and Potvin, P.G. (2012) Titanium(IV) Complexes of Disulfide-Linked Schiff Bases. Inorganic Chemistry, 51, 5138-5145. http://dx.doi.org/10.1021/ic202709x

[46] Form, G.R., Raper, E.S. and Downie, T.C. (1974) The Crystal and Molecular Structure of 2-amino-4-phenylthiazole Hydrobromide Monohydrate. Acta Crystallographica B, 30, 342-348. http://dx.doi.org/10.1107/S0567740874002792

[47] Fehlmann, M. (1979) The Crystal Structure of 2-methylaminobenzothiazole. Acta Crystallographica B, 26, $1736-1741$. http://dx.doi.org/10.1107/S0567740870004818

[48] Leovac, V.M., Novakovic, S.B., Bogdanovic, G.A. and Joksovic, M.D. (2007) Synthesis and Reaction of Schiff Base 4-(pyridin-3-ylmethylimino)-pent-2-en-2-ol with $\mathrm{FeCl}_{3}$. Structural Chemistry, 18, 337-341. 
http://dx.doi.org/10.1007/s11224-007-9148-z

[49] Lashanizadegan, M. and Sarkheil, M. (2012) Solvent-Dependent Synthesis and Mono-Hydrolysis of di-Schiff Base of (+--)trans-1,2-cyclohexanediamine and 2-pyridinecarboxaldehyde in $\mathrm{Cu}(\mathrm{II}), \mathrm{Co}(\mathrm{II})$ and $\mathrm{Zn}(\mathrm{II})$ Complexes. Journal of the Serbian Chemical Society, 77, 1589-1597. http://dx.doi.org/10.2298/JSC111203035L

[50] Papadopoulos, C.D., Lalia-Kantouri, M., Jaud, J. and Hatzidimitriou, A.G. (2007) Substitution Effect on New Co(II) Addition Compounds with Salicylaldehydes and the Nitrogenous Bases Phen or Neoc: Crystal and Molecular Structures of $\left[\mathrm{Co}^{\mathrm{II}}\left(5-\mathrm{NO}_{2} \text {-salicylaldehyde }\right)_{2} \text { (phen)], [Co }{ }^{\mathrm{II}}\left(5-\mathrm{CH}_{3} \text {-salicylaldehyde }\right)_{2} \text { (neoc)] and [Co }{ }^{\mathrm{II}} \text { (5-Cl-salicylalde- hyde }\right)_{2}$ (neoc)]. Inorganica Chimica Acta, 360, 3581-3589. http://dx.doi.org/10.1016/j.ica.2007.04.039

[51] Tangoulis, V., Lalia-Kantouri, M., Gdaniec, M., Papadopoulos, C., Miletic, V. and Czapik, A. (2013) New Type of Single Chain Magnet: Pseudo-One-Dimensional Chain of High-Spin Co(II) Exhibiting Ferromagnetic Intrachain Interactions. Inorganic Chemistry, 52, 6559-6569. http://dx.doi.org/10.1021/ic400557f

[52] Ahmed, I.S. and Kassem, M.A. (2010) Synthesis, Solvatochromaticity and Bioactivities of Some Transition Metal Complexes with 2-(R-benzylideneamino)-pyridin-3-ol Schiff Base Derivatives. Spectrochimica Acta A, 77, 359-366. http://dx.doi.org/10.1016/j.saa.2010.03.026

[53] Javadi, A., Shockravi, A., Koohgard, M., Malek, A., Ahmadi Shourkaei, F. and Ando, S. (2015) Nitro-Substituted Polyamides: A New Class of Transparent and Highly Refractive Materials. European Polymer Journal, 66, 328-341. http://dx.doi.org/10.1016/j.eurpolymj.2015.02.032

[54] Javadi, A., Najjar, Z., Bahadori, S., Vatanpour, V., Malek, A., Abouzari-Lotf, E. and Shockravi, A. (2015) High Refractive Index and Low-Birefringence Polyamides Containing Thiazole and Naphthalene Units. RSC Advances, 5, 91670-91682. http://dx.doi.org/10.1039/C5RA18898A

\section{Appendix A. Supplementary Data}

CCDC numbers of 1434260 and 1434261 contain the supplementary crystallographic data for compounds (1) and (2). These data can be obtained free of charge via http://www.ccdc.cam.ac.uk/conts/retrieving.html, or from the Cambridge Crystallographic Data Centre, 12 Union Road, Cambridge CB2 1EZ, UK; fax: (+44) 1223-336033; or e-mail: deposit@ccdc.cam.ac.uk. 